\title{
Effect of counselling on the psychiatric morbidity associated with mastectomy
}

\author{
P MAGUIRE, A TAIT, M BROOKE, C THOMAS, R SELLWOOD
}

\section{Summary and conclusions}

A controlled trial was conducted to determine whether counselling by a specialist nurse prevented the psychiatric morbidity associated with mastectomy and breast cancer. Seventy-five patients were counselled by the nurse and monitored during follow-up, while 77 patients received only the care normally given by the surgical unit. Counselling failed to prevent morbidity, but the nurse's regular monitoring of the women's progress led her to recognise and refer $76 \%$ of those who needed psychiatric help. Only $15 \%$ of the control group whose condition warranted help were recognised and referred. Consequently, 12 to 18 months after mastectomy there was much less psychiatric morbidity in the counselled group (12\%) than in the control group (39\%).

These findings highlight the high degree of psychiatric morbidity in patients who have undergone mastectomy and indicate the need to find ways of reducing this morbidity.

\section{Introduction}

Concern about the adverse psychological effects of mastectomy and breast cancer led us to appoint and train a nurse to counsel patients before and after surgery and to monitor their progress. ${ }^{1-3}$ We thought that she would prevent these problems and we carried out a study to test this.

\section{Patients and methods}

Using a random numbers table half the weeks during a 24-month period were designated as "counselling" weeks and the other half as "control" weeks. Women admitted for mastectomy in these weeks were assigned to the selected group. Patients in the counselling group were seen individually by a specialist nurse who gave them help before and after surgery. ${ }^{4}$ She later visited them at home and in the follow-up clinics to monitor their progress. Control patients received only the care normally given by the surgical unit.

A trained interviewer (CT or $\mathrm{MB}$ ) administered the present state examination to each woman shortly after surgery and three and 12 to 18 months later to determine the incidence of symptoms of anxiety, depression, and sexual problems. ${ }^{5}$ A shortened version of the BrownBirley life events schedule was also used to assess the occurrence of other stressful events. ${ }^{6}$ Depressive illness was diagnosed only when the patient reported a significant and persistent lowering of mood which had lasted four weeks or more and been accompanied by four of the following: loss of interest, impaired concentration, feelings of guilt, suicidal ideas, loss of energy, retardation or agitation, sleep disturbance, and changes in appetite or weight. Before anxiety could be considered morbid it also had to be significant, persistent, have lasted

\footnotetext{
University Hospital of South Manchester, West Didsbury, Manchester M20 8LR

P MAGUIRE, FRCPSYCH, senior lecturer in psychiatry

A TAIT, SRN, mastectomy nurse

M BROOKE, SRN, research nurse

C THOMAS, MRCPSYCH, senior registrar in psychiatry (now consultant liaison psychiatrist, Leicester Royal Infirmary, Leicester LE2 7LX) R SELLWOOD, FRCS, professor of surgery
}

at least four weeks, and have been accompanied by four of the following: impaired concentration, sleep disturbance, fatigability, somatic symptoms, and panic attacks. When patients still had cancer or experienced a recurrence symptoms such as fatigability which might have been due to the cancer were discounted when making the psychiatric ratings. Any psychiatric illness found was rated as mild, moderately severe, or severe, except sexual problems, which were categorised as moderately severe or severe.

Each interview was tape-recorded to permit checks of reliability. A psychiatrist (PM) listened to 30 tapes selected at random and rated them independently of either interviewer. Agreement between the interviewer and independent rater was high for the presence or absence of an anxiety state $(90 \%$ agreement; Cohen's $\mathrm{K}=0.79$; $\mathrm{p}<0.001)$ and depressive illness (95\% agreement; $K=0.86 ; p<0.001)$. The two interviewers then assessed 17 patients separately to check agreement between them, and this proved to be high (for anxiety $\mathrm{K}=0.73, \mathrm{p}<0.01$; for depression $\mathrm{K}=0.85, \mathrm{p}<0.01$.)

The first 100 women assessed 12 to 18 months after mastectomy were asked by the interviewer to complete a series of linear analogue scales on their own the next day and post them back. These were designed to measure mood and to act as a check on the interviewers' assessments. Each scale was a $100-\mathrm{mm}$ line with a pair of descriptive statements such as "Not at all depressed" and "Very depressed" placed at the end. Patients were asked to mark these lines to show how they had been feeling over the previous four weeks.

One hundred and seventy-two women were recruited into the study but five refused to co-operate, two moved out of the area, and 13 became too ill to be interviewed or died. Thus assessments were completed on 152 women. The counselling and control groups proved well matched on variables which influence psychiatric morbidity, including stage of disease, other treatments, age, marital status, social class, previous psychiatric illness, and other stressful events.

\section{Results}

Before admission-During the three months before admission 8 patients in the counselling group and 5 controls had suffered from an anxiety state, depressive illness, or sexual problem (table I).

Three months after mastectomy-Twenty-three patients in the counselled group and 25 controls were found to have an anxiety state (table I). Depressive illness was also equally common in counselled and control groups. Sexual problems could be rated only in the 50 counselled patients and 48 controls who had a satisfactory sex life before surgery; such problems were more common in counselled patients $(20)$ than in controls (15). Altogether $29(39 \%)$ of those seen by the nurse and $33(43 \%)$ of those given only routine care were suffering from an anxiety state, depressive illness, sexual problem, or combination of these.

Twelve to 18 months after mastectomy-Far fewer of the patients who received counselling had an anxiety state (table I). Depressive illness was also less common in the counselled group than in the control group. Sexual problems were found in 15 controls but in only four of those counselled. One or more of these psychiatric problems was found in $30(39 \%)$ controls and nine $(12 \%)$ counselled patients.

Self-reported data-The mood scales were completed and returned by 87 of the 100 women asked to do so. The control group reported much more anxiety (mean $( \pm S D) 42 \cdot 7 \pm 29 \cdot 5)$ than the counselled group $(17 \cdot 2+22.9 ; t=10.9 ; \mathrm{df}=85 ; \mathrm{p}<0.001)$. Depression scores were also higher in the control group $(43.3 \pm 37.7)$ compared with the counselled group $(15.9 \pm 22.8) ; t=6.5$, df $85 ; \mathrm{p}<0.001)$.

Duration of psychiatric morbidity-The interviewers judged that episodes of morbid anxiety, depression, or sexual problems had occurred at some stage since mastectomy in $38(51 \%)$ of the counselled group and $41(53 \%)$ of the control group (table II). Episodes of morbid anxiety (lasting a mean of $6.4 \pm 2.4$ months) and depression (6.2 \pm 2.5 months) were much shorter in patients who received counselling than in control subjects (for anxiety $10.8+5.7$ months, $t=4.3$; 
df $68 ; \mathrm{p}<0.001 ;$ for depression $10.0 .5 \cdot 7 ; t=3.5 ;$ df $70 ; \mathrm{p}<0.001$ ). The duration of sexual problems did not differ significantly between the counselled (10.8 $5 \cdot 7)$ and control groups (13.1 $5 \cdot 1$ months).

Recognition of psychiatric morbidity-The specialist nurse recognised $34\left(89^{\prime \prime}\right)$ of the 38 women in her group who developed psychiatric problems, but these difficulties were detected in only $9(22 \%)$ of the 41 affected controls $\left(\mathrm{x}^{2}=35.4 ; 1 \mathrm{df} ; \mathrm{p}<0.001\right)$ by those concerned in their care. The nurse referred 29 of the 34 patients in whom she recognised problems to a psychiatrist (PM) for advice. Only six of those with problems in the control group were similarly referred. Another patient in the counselled group was referred by the surgeons. Thus, $30(40 \%)$ patients were referred from this group compared with only six $\left(8^{\prime \prime}{ }_{1}\right)$ controls $\left(K^{2}=20 \cdot 1,1 \mathrm{df}, \mathrm{p}<0 \cdot 001\right.$. recognising and referring such patients if they were given a similar brief training. We did not use patients who had already undergone mastectomy as counsellors but accept that they could help considerably if problems of selection and training were resolved.

The poor recognition of psychiatric morbidity in the control group suggests that the aftercare of patients who have undergone mastectomy should not be based on referrals by the surgical team. It also emphasises the need to train doctors, nurses, and social workers in the relevant assessment skills and increase their awareness of factors that prevent patients disclosing their difficulties. ${ }^{7} 8$

TABLE I-Psychiatric morbidity before admission and at 3 and 12-18 months after mastectomy. Results are numbers (and percentages) of patients

\begin{tabular}{|c|c|c|c|c|c|c|}
\hline \multirow{2}{*}{$\begin{array}{l}\text { Psychiatric } \\
\text { morbidity }\end{array}$} & \multicolumn{2}{|c|}{ Anxiety state } & \multicolumn{2}{|c|}{ Depressive illness } & \multicolumn{2}{|c|}{ Sexual problems } \\
\hline & $\begin{array}{c}\text { Counselling } \\
(\mathrm{n}=75)\end{array}$ & $\begin{array}{l}\text { Control } \\
(n=77)\end{array}$ & $\begin{array}{l}\text { Counselling } \\
(n=75)\end{array}$ & $\begin{array}{l}\text { Control } \\
(\mathrm{n}=77)\end{array}$ & $\begin{array}{l}\text { Counselling } \\
(\mathrm{n}=50)\end{array}$ & $\begin{array}{l}\text { Control } \\
(n=48)\end{array}$ \\
\hline \multicolumn{7}{|c|}{\begin{tabular}{cccc}
\multicolumn{5}{c}{ Morbidity before admission for mastectomy } \\
$69(92)$ & $73(95)$ & $70(93)$ & $74(96)$ \\
$4(5)$ & $3(4)$ & $2(3)$ & $2(3)$ \\
$2(3)$ & $1(1)$ & $-3(4)$ & $1(1)$ \\
0 & 0 & 0 & 0
\end{tabular}} \\
\hline \multicolumn{7}{|c|}{ 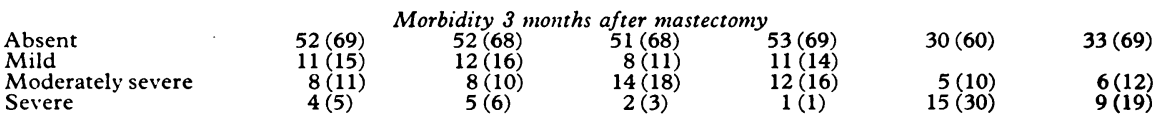 } \\
\hline \multicolumn{7}{|c|}{\begin{tabular}{cccc}
\multicolumn{4}{c}{ Morbidity 12-18 month after mastectomy* } \\
$69(92)$ & $54(70)$ & $71(95)$ & $54(70)$ \\
$4(5)$ & $6(8)$ & $1(1)$ & $8(10)$ \\
$2(3)$ & $15(19)$ & $3(4)$ & $13(17)$ \\
0 & $2(3)$ & 0 & $2(3)$
\end{tabular}} \\
\hline
\end{tabular}

*For comparison between counselling and control groups for incidence of anxiety states $\chi^{2}=10.4,1 \mathrm{df}, p<0.01$ for depressive illness $\chi^{2}=14 \cdot 0,1 \mathrm{df}, \mathrm{p}<0 \cdot 001$; for sexual problems $\%^{2}=6 \cdot 6,1 \mathrm{df}, \mathrm{p}<0 \cdot 02$. ( $\%^{2}$ were calculated using Yates's correction factor.)

One husband had died and one had left his wife since the 3 -month assessment.

TABLE II-Episodes of psychiatric morbidity occurring since mastectomy. Results are numbers (and percentages) of women who had an episode at any stage since mastectomy

\begin{tabular}{lccccrr}
\hline \multirow{2}{*}{$\begin{array}{c}\text { Psychiatric } \\
\text { morbidity }\end{array}$} & \multicolumn{2}{c}{ Anxiety state } & \multicolumn{2}{c}{ Depressive illness } & \multicolumn{2}{c}{ Sexual problems } \\
\cline { 2 - 7 } & Counselling & Control & Counselling & Control & Counselling & Control \\
\hline Absent & $42(56)$ & $40(52)$ & $42(56)$ & $38(49)$ & $30(60)$ & $28(58)$ \\
Mild & $18(24)$ & $18(23)$ & $17(22)$ & $19(25)$ & $5(10)$ & $7(15)$ \\
Moderately severe & $11(15)$ & $12(16)$ & $11(15)$ & $16(21)$ & $15(30)$ & $13(27)$ \\
Severe & $4(5)$ & $7(9)$ & $5(7)$ & $4(5)$ & & \\
\hline
\end{tabular}

\section{Discussion}

We were disappointed that counselling failed to prevent problems but believe that we were naive to expect this. The news that they have cancer and will lose a breast is a serious blow for most women even when they are prepared for it.

The nurse's monitoring of progress enabled her to recognise and refer most of those who needed psychiatric help. Many of these patients suffered from both morbid anxiety and depression and usually responded well to brief psychotherapy and tricyclic or tetracyclic antidepressants. Those with sexual problems proved more difficult to help. They could not adapt to the loss of a breast and were loth to accept any help which meant that they or their spouses had to look at the scar. We consider that they would benefit from reconstructive surgery.

We were encouraged that the recognition, referral, and treatment of patients in the counselling group substantially reduced the psychiatric morbidity. This reduction might have been achieved more rapidly had some women not delayed accepting psychiatric help because of the associated stigma. This delay might be avoided if the specialist nurse referred patients who needed help to their general practitioner. District nurses and health visitors might prove as able as the nurse in
The psychiatric morbidity was high in both counselled and control groups but it is worth noting that 72 of the 152 patients assessed suffered advanced or recurrent disease or were given adjuvant chemotherapy or radiotherapy. Moreover, the incidence of problems in the control group 12 to 18 months after surgery was similar to that found in a previous study. ${ }^{3}$ These findings highlight the need to continue to explore ways of reducing or preventing the psychiatric morbidity associated with mastectomy and breast cancer.

The counselling scheme was based on work supported by the Cancer Research Campaign and its evaluation was funded by the North-west Regional Health Authority.

Requests for reprints should be addressed to Dr P Maguire, Department of Psychiatry, Withington Hospital, West Didsbury, Manchester M20 8LR.

\section{References}

1 Morris T. Psychological adjustment to mastectomy. Cancer Treatment Rev 1979;6:41-61.

2 Baum M, Jones E. Counselling removes patients' fear. Nursing Mirror 1979 March 8: 39-41. 
${ }^{3}$ Maguire GP, Lee EG, Bevington DJ, Kuchemann CS, Crabtree RJ, Cornell CE. Psychiatric problems in the first year after mastectomy. Br Med F 1978;i:963-5.

${ }^{4}$ Maguire P, Tait A, Brooke M, Sellwood R. Emotional aspects of mastectomy: planning a caring programme. Nursing Mirror 1980 January $17: 35-7$.

5 Wing JK, Nixon J, Mann A, Leff JP. Reliability of the PSE (ninth edition) used in a population study. Psychol Med 1977;7:505-16.
${ }^{6}$ Brown GW, Harris T. Social origins of depression. London: Tavistock Press, 1978.

7 Maguire P, Tait A, Brooke M. Mastectomy: a conspiracy of pretence. Nursing Mirror 1980, January 10: 17-19.

${ }^{8}$ Sanson-Fisher R, Maguire P. Should skills in communicating with patients be taught in medical schools? Lancet (in press).

(Accepted 9 October 1980)

\title{
Glial origin of rapidly adhering amniotic fluid cells
}

\author{
PERTTI AULA, HARRIET vON KOSKULL, KARI TERAMO, OLAVI KARJALAINEN, \\ ISMO VIRTANEN, VELI-PEKKA LEHTO, DORIS DAHL
}

\section{Summary and conclusions}

Rapidly adhering cells (RA cells) from the amniotic fluid of a pregnancy with fetal anencephaly were investigated by immunofluorescence assay with an antiserum against glial cells. After 24 hours' cultivation a high proportion of the cells showed positive glial-specific fluorescence, whereas no staining was seen in cells from samples of normal amniotic fluid. At the 24 th week the mother was delivered of a stillborn infant with anencephaly.

Immunofluorescence staining of $R A$ cells with glialspecific antiserum may be used for the differential diagnosis of fetal abnormalities associated with a high $\alpha$-fetoprotein concentration in amniotic fluid.

\section{Introduction}

Amniotic fluid from pregnancies complicated by fetal anencephaly or spina bifida contains an excess of cells that adhere rapidly to glass or plastic under tissue-culture conditions. ${ }^{1}$ Testing for these cells has been proposed as an adjunct to $\alpha$-fetoprotein assays in the prenatal diagnosis of neural-tube defects. ${ }^{2}$ These rapidly adhering cells (RA cells) may show extensive variation in morphology, and Gosden and Brock ${ }^{3}$ classified four different types in amniotic fluid from pregnancies complicated by fetal anencephaly and spina bifida. The origin of the cells has not been proved, though their gross morphological appearances suggest that they originate from the central nervous system. ${ }^{4}$ We describe a pregnancy complicated by anencephaly in which immunofluorescence studies showed the cells to be of glial origin.

\footnotetext{
Laboratory of Prenatal Genetics, Departments I and II of Obstetrics and Gynaecology, University of Helsinki, Finland

PERTTI AULA, MD, medical geneticist

HARRIET vON KOSKULL, MSC, geneticist

KARI TERAMO, MD, senior obstetrician

OLAVI KARJALAINEN, MD, acting professor of obstetrics and gynaecology

Department of Pathology, University of Helsinki, Finland

ISMO VIRTANEN, MD, senior scientist

VELI-PEKKA LEHTO, MD, assistant of pathology

Department of Neuropathology, Harvard Medical School, and Spinal Cord Injury Service, West Roxbury Veterans Administration Medical Center, Boston, USA

DORIS DAHL, PHD, assistant professor of neuropathology
}

\section{Patient and methods}

A 28-year-old primipara who for several years had been taking phenytoin and carbamazepine as anticonvulsant treatment was found to have a raised serum $\alpha$-fetoprotein concentration at the 20 th week of pregnancy $(183 \mu \mathrm{g} / \mathrm{l})$. Ultrasonography during the 23rd week suggested that the fetus had anencephaly. Amniotic fluid sampled by amniocentesis yielded an $\alpha$-fetoprotein concentration of $56.3 \mathrm{mg} / 1$ which was over 50 standard deviations above the expected mean for that week; total cell count was $210 \times 10^{6} / 1$. For cell cultures about 2000 cells from the amniotic fluid were inoculated into tissue-culture dishes with small coverslips. After 24 hours the cells were fixed in $-20^{\circ} \mathrm{C}$ methanol for 30 minutes, dried in air, and examined by phase-contrast microscopy and indirect immunofluorescence microscopy, using a glial-cell specific, glial fibrillary acidic protein antiserum (anti-GFA). ${ }^{6}$ The cells were also stained with an antiserum against purified human epidermal keratin polypeptides raised in rabbits and affinity-purified in a keratin-sepharose GL4B column.

\section{Results}

Several types of cells with different morphology were seen on the coverslips after 24 hours in culture, but the glial-specific fluorescence was evident in only a proportion of the cells (figure $(b, d)$ ). The cells showing glial-specific staining were either long bipolar cells, filamentous pseudopodial cells, large vacuolated cells with inclusions, or giant cells with multiple nuclei. ${ }^{3}$ The cells that were negative after anti-GFA staining were morphologically similar to cells in normal amniotic fluid cultures, being either fibroblastoid (figure $(c)$ ) or showing keratin-specific fluorescence on immunofluorescence staining (figure $(f)$ ), a property typical of various epithelial cells. ${ }^{8}$ Severa 24-hour cell cultures from amniotic fluid samples taken from normal pregnancies for karyotype testing showed no glial-specific fluorescence.

Raised $\alpha$-fetoprotein concentrations, the findings on ultrasonography, and the presence of RA cells strongly suggested that the fetus had anencephaly. At 24 weeks the mother was delivered of a stillborn infant with typical anencephaly. Necropsy showed a large defect in the cranial end of the neural tube, permitting direct contact between spinal and amniotic cavities.

\section{Discussion}

These results suggest that the RA cells in amniotic fluid from a pregnancy complicated by fetal anencephaly are glial cells, originating from the central nervous system. We found no such cells in several normal pregnancies. The indirect immunofluorescence method with a glial-specific antiserum used in our study is highly specific for glial cells. ${ }^{6}$ ? Interestingly, related results suggesting the neural origin of RA cells were reported by Sarkar et al. ${ }^{9}$ They used a different cellular marker in immunofluorescence in a pregnancy that retrospectively resulted in an anencephalic fetus. 